\title{
COMMUNICATION
}

\section{RIGHTS OF THE INDIVIDUAL IN COURT*}

\author{
By Gideon Hausner**
}

Fifteen years ago I had the privilege of delivering from the rostrum of an International Convention of Lawyers and Jurists an account of the basic problems of our civil liberties, as reflected in the decisions of our Courts. I wish to up-date that account in so far as the activities of our Courts are concerned. In the course of the last fifteen years Israel has had to go to war on three occasions: the Sinai War, the Six-Day War and the War of Attrition. The country has more than doubled its population. We have continued with the ingathering of the exiles, making at the same time a serious effort to advance economically and to catch up with the technology of our times.

All this was taking place on a background of stiffening resistance to our very existence on the part of our neighbours. Moreover, a joint Soviet-Arab patronage produced a renewed version of the Protocols of the Elders of Zion, ascribing to Israel and to the Zionist movement a sinister international plot, in collusion with shady imperialistic forces, to defeat all progress in the world generally, and to bring about the downfall of the Arab states in particular.

Israel had incredulously observed all this and instead of directly rebutting such absurd statements, we decided to proceed on our path of creating a new reality of life in our country which by its existence will effectively give the lie to such vicious propaganda.

But we have been labouring under adverse conditions. The traumatic possibility of being wiped out without any interference on the part of the rest of the world had been driven home to everybody by the revelations at the Eichmann Trial which unfolded our national tragedy during the Nazi

* This comment is additional to and should be read with reference to an article under the same title presented by the author at the International Congress of Jewish Lawyers and Jurists in Jerusalem, August 1973. The full text of the original article appears in (1974) 9 Is.L.R. 477.

* M.K. Cabinet Minister. 
period with the rest of the world generally standing aside. The double standards applied to us in comparison with others were repeatedly demonstrated in the international arena, and again very recently when Israel was unanimously condemned by the Security Council for her measures of self-defence without a word of criticism being murmured against her attackers.

Under such circumstances, there might have been a temptation to have recourse to a strong Executive and to allow the authorities a greater freedom in the exercise of emergency powers. Yet nothing of the kind happened. No special powers were vested in the authorities. Quite the contrary: the courts continued to function unhindered, enjoying ever wider respect and confidence, and maintaining a substantial control over the Government in almost every matter. There was no soft pedalling of the liberties of the individual. We preferred to adhere to Lord Atkin's famous dictum that laws ought not to be silent amidst the clash of arms and should speak the same language at war as at peace. The courts have consistently upheld the rule of law whenever the occasion arose. Though we follow the constitutional pattern of England rather than that of the United States, our constitution being as Dicey had put it "part of the ordinary law of the land", still the Supreme Court declared a law duly passed by the Knesset to be virtually of no effect. In a system in which the courts are not yet vested with any power to control parliamentary legislation this constitutes a high water mark of judicial control. You will find the case referred to in my article presented at the Congress.

The High Court of Justice found no difficulty in continuing to protect civil rights. The foundation already existed as laid down in that Court's decisions during the first decade. This was a sufficiently strong foundation for the subsequent instances of interference with arbitrary decisions. In the economic sphere, the Court ruled that a monopoly is illegal since it curtails the liberty of occupation of other interested parties. ${ }^{1}$ In the sphere of the freedom of expression, the Court ordered to restore part of a newsreel which the censorship had cut out since the police had been allegedly presented there as too brutal.

An authority which will assume the power of laying down that an individual should know will eventually lay down what he ought to think ,...

said the High Court, allowing the petition. ${ }^{2}$

In an unbroken chain of decisions, the High Court of Justice has insisted that the primary duty of the authorities is to apply equal treatment to

$1 Y$. Miller, Engineer (Agencies and Import) Ltd. v. Minister of Transportation et al. (1961) (III) 15 P.D. 1989.

2 Ulpanei Hasrata B'Israel Ltd. v. Geri and the Films and Theatre Censorship Board (1971) (II) 26 P.D. 811, 814. 
everybody and to refrain from taking into consideration matters which are irrelevant to the strict justice of the case. Whenever an official did not comply with this duty, that alone was always sufficient ground for the Court's intervention, whether the aggrieved individual had suffered an injury to a right vested in him by law or whether the authority had been acting under its general discretion. Moreover, doubts arising in borderline cases were resolved in favour of the individual.

Through its decisions, the High Court of Justice had implanted into the state officials a respect for civil rights. The whole state machinery has now the High Court in mind when deciding on a matter which could bring about a legitimate grievance. Senior officials are measuring their success in office by the scarcity of High Court cases brought against them. A former Director General of an important economic ministry considered it a feather in his cap that in the course of a long term of office he was brought only twice to the High Court and was vindicated on both occasions,

Legality has, therefore, not only been preached but also practically implemented. A procedure developed under which an aggrieved party, even before going to Court, could apply to the Attorney General. If upon investigation, the latter found that there was merit in the complaint, he would so inform the official involved, adding that should the matter be brought to the bar of the High Court of Justice, he, the Attorney General, would not defend the authorities. Since by law government agencies ought to be represented in court in such matters by the Attorney General's department, this means in practice that the official concerned must give way.

Obviously, however, matters of difficulty also arose from time to time. In some instances even civil rights had to give way when other considerations were involved. The question was always what interest, if any, is to be rated higher than the liberty of the individual? Some of these cases are in the realm of security, where the Court will occasionally, though not always, stop short of interfering and limit itself to a more formal examination of the authorities' measures. Still as I mentioned in the article presented at the Congress, Court orders are sometimes made against the authorities even in these delicate matters.

Difficulties arising from present-day realities were not the only ones to plague the High Court. There were others which stem from the ancient past of the nation and belong to the realm of the Religion-State relationship.

The uniqueness of our position in this respect is well-known. Israel is a secular state which in its Declaration of Independence has solemnly promised to secure civil rights. This, however, clashes with the desire to maintain unity between the State and the Religious organs. Though Moslem Religious Courts enjoy an even wider scope of jurisdiction than the Jewish Courts, the practical human difficulties which have come to the notice of the public arose rather from the decisions of the Rabbinical Courts. The issue is sensitive emotionally and politically explosive. Endless demonstrations, 
some even involving serious clashes, were held to prevent desecration of the Sabbath or to prohibit autopsies. Cabinets have twice been toppled on religious matters. Even activities in marginal religious affairs were far from being smooth. Elections to the Chief Rabbinate were nullified by the Court on two occasions and required $e x$ post facto validating legislation.

The issue is more fully described in my original article. At the risk of repetition, I shall briefly say that while the Orthodox consider Israel as an opportunity to revive a society abiding by religious precepts, the other parts of the population demand a secular, modern way of life. They will gladly allow full religious freedom to the observant but they require freedom for themselves to live in their own way. The greater part of the population has a keen respect for tradition and is prepared to meet such religious demands as can be complied with within the framework of a modern society.

Even in this sphere, the High Court of Justice managed to introduce some important innovations. One such innovation was subsequently nullified by legislation. It concerned instructions for the registration of the issue of mixed marriages. The High Court, for the first and only time in its history, was composed for the occasion of nine out of its ten judges. The ruling was given by a five-to-four majority. ${ }^{3}$

Another instance concerned the prohibitive impediments to a religious marriage when the High Court, realizing that it would be futile to send the parties back to the Rabbinical Court, had itself ordered a couple to be registered as married, though this power is usually reserved by law to the Rabbinical Courts. ${ }^{4}$

Sometimes an exigency of unprecedented circumstances will cause the Court to abstain from the enforcement of a civil right. When Orthodox Jews wished to pray on the Temple Mount a terrain in which two mosques are located, thus interferring with the susceptibilities of the Moslem population, the Court refused to order the police to secure the safety of such prayers there by the Jews. In explanation, the Court said that there is probably no precedent in the whole world for such a unique situation and one so fraught with dangers. ${ }^{5}$ Thus, while the High Court has been advancing civil liberties even in this sphere, the same cannot be said either about the Knesset or about the Government. They remained inactive in the face of the serious human issues involved. I say this fully sharing personally the responsibility of the Knesset in this respect.

3 Benjamin Shalit (in his name and for his children) v. The Minister of Interior and Registration Clerk, Haifa (1969) (II) 23 P.D. 477; (1971) S.J. special volume, p. 35.

4 Rudnicik v. The Rabbinical Court of Appeal (1970) (I) 24 P.D. 704.

5 Hugim Leumi'im (registered association) v. The Minister of Police (1970) (II) 24 P.D. 141, 166-8. See also Klein, "The Temple Mount Case" (1971) 6 Is.L.R. 257. 
There exists, therefore, a marked divergence between the legal and the administrative trends in this matter. This is certainly not due to the lack of a deep respect for religious values on the part of the Courts, but is predicated on a true insight into the realities of our life which is threatened with a serious rift.

In an article written specially for the Congress, Prof. Amnon Rubinstein, who teaches Constitutional Law at the University of Tel Aviv, pointed to some serious deficiencies in the rule of law in our country. He rightly claims that charity begins at home. While not doubting the validity of Prof. Rubinstein's constructive criticism, may I say that it does not concern the Courts. In so far as other State agencies are concerned, may I plead, in mitigation, a statement from de Tocqueville:

In democracies men are never stationary. A thousand chances waft them to and fro. Their life is always the life of unforeseen circumstances. They are obliged to do things which they have imperfectly learned, to say things which they have imperfectly understood and to devote themselves to work for which they are unprepared. ${ }^{6}$

I wish, however, to associate myself with Prof. Rubinstein's plea that our Convention should deal in depth with the basic problems of Israel law.

On my part I will say that in the existing circumstances a great step forward will be made by the adoption of a constitution, which would formally and rigidly safeguard civil liberties in a manner independent of the efforts of the judiciary. Such a document will sum up our to-date achievements in the field and set the course for a secure future. It will also become an important educational instrument by making the knowledge of our liberal democracy and the ways for its performance, available to everybody and subject to the criticism of the ordinary citizen. An objective gauge of civil rights will be established. There is no valid argument against the adoption of such a constitution and the sooner we do so, the better.

It is a matter of regret that a Bill of Rights ${ }^{7}$ which had been carefully studied and lengthily debated by the Law Committee of the Knesset did not reach the stage of fruition, though finally prepared for submission to the vote. The Knesset will have to adopt it as well as to provide the measures for its observance. Without divulging secrets from the Committee's deliberations, I wish to give you the gist of the prepared declaration of basic rights as adopted by the Law Committee. The first of its 20 paragraphs says: "The individual is free and no limitations or duties are to be imposed on him otherwise than by law." This is the basic statement of the Rule of Law. The remaining paragraphs enumerate the established civil rights, with special emphasis on the principle that all are equal before the law and no discrimination may be made on the grounds of race, sex,

6 Democracy in America, vol. 2, p. 274.

7 (1973) H.H. no. 1085 , p. 448. 
nationality, community, country of origin, religion, social standing or organizational or political affiliation. Full liberty of the worship of God is secured. There is a wide provision for the freedom of expression. The individual's privacy is safeguarded. The last two provisions deserve a full statement. They read:

A legal power that relates to the rights of an individual shall only be exercised in fair proceedings, without bias and without any irrelevant considerations.

Where any statute is capable of various interpretations, the interpretation that is more consistent with upholding the rights of the individual and less inclined to restrict them or permit their restriction shall be preferred.

The provisions of a statute that is enacted after the commencement of this Law and contains a provision contrary to a provision of this Law shall be void.

Once this Bill of Rights is made law with a due provision for its supremacy, we shall have made an important step forward.

Reverting now in a concluding remark to the performance of our judiciary in the preservation of our civil liberties, one can express, on the whole, a sincere appreciation on the manner in which it has dealt with civil rights. A Supreme Court Judge formulated this sentiment in a leading case: ${ }^{8}$

This Court is the safest and most objective mainstay which the individual may have in his disputes with the authorities.

An ancient Jewish prayer has thus been answered. The Jew has been praying for centuries to God: "Restore our Judges as in the days of old". Now a prophecy of Isaiah has still to be fully implemented: "Then justice shall make its home in the wilderness and righteousness dwell in the grassland; when righteousness shall yield peace and its fruit be quietness and confidence for ever". 9

8 Miron v. Minister of Labour (1970) (I) 24 P.D. 340.

9 Isaiah $32: 16-17$. 